\title{
Atmospheric learning: Pengembangan digital mind maps berbantuan mind mapping software untuk siswa Geografi SMA
}

\author{
Selvi Nanda Oktavia, Ardyanto Tanjung*, Listyo Yudha Irawan \\ Universitas Negeri Malang, Jl. Semarang No. 5 Malang, Jawa Timur, Indonesia \\ *Penulis korespondensi, Surel: ardyanto.tanjung.fis@um.ac.id
}

Paper received: 02-03-2021; revised: 15-03-2021; accepted: 30-03-2021

\begin{abstract}
Learning media is a tool for students to make learning easier. Mind map digital is a learning media in the form of mind maps with the help applications of mindset mind manager presentation. The main objective of developing mind maps is to produce digital-based products for class $\mathrm{X}$ students on material atmospheric. This media can be a reference for the latest material, examples and learning resources around the atmosphere to provide students with an easy understanding of the lesson. The mind map digital developed has been tested internally by media experts and material experts. The final results are in the form of a digital mind map product design that has been revised based on suggestions and recommendations from each validator. This research and development use the modified ADDIE's model only in the ADD section with research procedures namely goal formulation, media design, media validation. The research subjects were 28 students of class X IPS 4 in SMA 2 Batu. The research data used included the results of the media feasibility questionnaire, while the techniques data analysis used descriptive analysis to process the trial data. The results showed that digital mind maps were feasible to be used in the learning process with each gaining scores from material experts 98 percent and media experts 79 percent. Then the assessment or product response from students as research subjects get a value of 80.02 percent.
\end{abstract}

Keywords: learning media; mind map digital; atmospheric

\begin{abstract}
Abstrak
Media pembelajaran merupakan alat bantu untuk peserta didik agar memberikan kemudahan dalam belajar. Mind map digital adalah media pembelajaran dalam bentuk peta pikiran dengan berbantuan aplikasi presentasi mindjet mindmanager. Tujuan utama pengembangan mind map adalah menghasilkan produk berbasis digital untuk peserta didik kelas X pada materi atmosfer. Media ini dapat menjadi rujukan materi, contoh, dan sumber belajar terbaru seputar atmosfer untuk memberikan peserta didik kemudahan dalam memahami pelajaran. Mind map digital yang dikembangkan telah di uji internal oleh ahli media dan ahli materi. Hasil akhir berupa rancangan desain produk mind map digital yang telah direvisi berdasarkan saran dan rekomendasi dari masingmasing validator. Penelitian dan pengembangan ini menggunakan model ADDIE yang dimodifikasi hanya pada bagian ADD dengan prosedur penelitian yaitu perumusan tujuan, desain media, validasi media. Subjek penelitian adalah 28 peserta didik kelas X IPS 4 SMA 2 Batu. Data penelitian yang digunakan meliputi hasil angket kelayakan media, sedangkan teknik analisis data menggunakan analisis deskriptif untuk mengolah data hasil uji coba. Hasil penelitian menunjukkan bahwa mind map digital layak digunakan dalam proses pembelajaran dengan masing-masing memperoleh nilai dari ahli materi 98 persen dan ahli media 79 persen. Kemudian penilaian atau tanggapan produk dari peserta didik selaku subjek penelitian mendapatkan nilai 80,02 persen.
\end{abstract}

Kata kunci: media pembelajaran, mind map digital, atmosfer

\section{Pendahuluan}

Media pembelajaran merupakan alat bantu yang berperan penting dalam menunjang pembelajaran sehingga memudahkan peserta didik dalam belajar. Penggunaan media 
pembelajaran dapat menciptakan pembelajaran yang efektif dan efisien. Efektif dalam pembelajaran dimaksud dapat tercapaianya tujuan belajar yang telah direncanakan. Sedangkan, efisien berarti tepat guna sesuai materi yang diajarkan di kelas.

Memasuki abad 21, kemajuan teknologi dan informasi berkembang dengan pesat. Segala aspek kehidupan tidak terlepas dari andil teknologi, khususnya dalam dunia pendidikan. Perkembangan teknologi dapat menjadikan pembelajaran konvensional beralih pada pembelajaran berbasis digital. Perkembangan teknologi memiliki peran penting sebagai pendukung dalam proses pembelajaran. Salah satu bentuk pemanfaatan teknologi berupa pengembangan media pembelajaran.

Pengembangan media berupa mind map digital sebagai solusi pemenuhan terhadap kebutuhan belajar. Peserta didik saat ini termasuk generasi milenial yang dalam kegiatan sehari-hari menggunakan laptop (PC) dan teknologi, terutama internet. Dunia pendidikan harus bisa beradaptasi dan menyediakan media berbasis laptop (PC) untuk mengimbangi gaya belajar peserta didik generasi milenial, sehingga dapat mengubah cara pandang peserta didik yang beranggapan bahwa belajar menjadi hal yang menyenangkan dengan penggunaan teknologi. Media mind map digital menjadi salah satu solusi dalam membantu pembelajaran peserta didik.

Mind map digital merupakan peta pikiran yang dikemas dalam bentuk digital yang menampilkan catatan pelajaran secara ringkas dalam bentuk mind map berbantuan aplikasi mindjet mindmanager. Mindjet mindmanager dapat digunakan untuk membuat presentasi peta pikiran, sehingga membantu mempercepat dalam pembuatan peta pikiran dengan menarik. Pendapat Nanang (2013) menjelaskan bahwa, "mindjet mindmanager sangat fleksibel dapat mengganti dan memodifikasi peta pikiran. Software ini memiliki kemampuan untuk membuat tautan (link) dengan aplikasi lain, misalnya power point, word, excel, dan macromedia flash".

Tujuan utama pengembangan mind map digital adalah menghasilkan produk berbasis digital untuk peserta didik kelas X pada materi atmosfer. Media ini dapat menjadi rujukan materi, contoh, dan sumber belajar terbaru seputar atmosfer untuk memberikan kemudahan dalam pemahaman belajar. Pengembangan media berupa mind map digital bertujuan untuk menyediakan media berbasis digital yang dapat dibuka melalui alat elektronik sebagai pendukung proses pembelajaran. Mind map digital dapat digunakan oleh guru maupun peserta didik sebagai acuan untuk memberikan pemahaman dalam belajar.

Materi atmosfer dipilih sebagai pokok pembahasan pengembangan media karena atmosfer termasuk pada pelajaran geografi fisik yang didalam pembahasan terdapat bagian materi yang sulit untuk diingat dan memiliki subtema pembahasan yang banyak serta memiliki keterkaitan. Sesuai dengan pernyataan Fatkurrohman (2012) bahwa "Materi atmosfer merupakan kajian geografi fisik yang membahas tentang proses dan objek yang terjadi secara alamiah dalam jangka waktu yang lama, sehingga dalam penjelasannya tidak cukup hanya dengan lisan." Materi atmosfer adalah pembelajaran tentang lapisan udara yang dapat dirasakan namun tidak dapat diamati secara langsung prosesnya. Materi atmosfer juga membahas tentang unsur dan proses pembentukan cuaca dan iklim serta pengaruhnya terhadap kehidupan makhluk hidup di permukaan bumi. Materi atmosfer memiliki beberapa komponen pembahasan yang saling terkait. Oleh karena itu, diperlukan media pembelajaran yang relevan untuk menunjang tercapainya pemahaman pembelajaran. 
Pengembangan media berupa mind map digital sudah pernah dilakukan oleh Siwi (2016) dengan judul Pengembangan Media Pembelajaran Berbasis Mind Map Menggunakan Aplikasi Mindjet Mindmanager Untuk Meningkatkan Hasil Belajar Fisika Materi Pokok Momentum, Impuls, Dan Tumbukan kelas X semester 2 SMAN 11 Yogyakarta tahun ajaran 2016/2017. Hasil penelitian dan pengembangan tersebut menunjukan mind map layak digunakan sebagai sumber belajar dengan kriteria kelayakan di atas $75 \%$. Perbedaan pengembangan e-mind map dari penelitian tersebut terletak pada materi kajian. Mind map digital untuk peserta didik SMA kelas X pada materi atmosfer yang akan dikembangkan telah disesuaikan dengan materi geografi SMA kelas X sesuai dengan Kurikulum 2013.

Media mind map digital untuk peserta didik SMA kelas X pada materi atmosfer merupakan media yang berbasis digital sehingga peserta didik dapat dengan mudah mengaksesnya. Mind map digital didalamnya terdapat konsep materi pembelajaran yang dibentuk dalam peta pikiran dari setiap sustema dengan contoh berupa gambar, video, dan penjelasan yang ringkas. Selain itu, format file yang dihasilkan berupa file HTML5 ini berbasis website. Pembuatan mind map digital diawali dengan menggunakan aplikasi mindjet mindmanager sebagai alat pendukung dan berbantuan dengan aplikasi autoplay media studio sebagai tampilan awal atau cover media pembelajaran yang berfungsi untuk background produk sesuai tema materi. Kemudian membuat diagram alur sebagai langkah selanjutnya.

Mind map memiliki kelebihan, yaitu: 1) dapat mengemukakan pendapat secara bebas; 2) catatan lebih padat dan jelas; 3) Catatan lebih terfokus pada inti materi. Berdasarkan kelebihan mind map memberikan kemudahan kepada peserta didik dalam belajar, tampilan dalam mind map juga bervariasi dalam berbagai bentuk peta pikiran sehingga peserta didik lebih mudah mengingat materi yang dikemas dalam visual yang menarik. Selain itu terdapat penjelasan dari Alamsyah (dalam Muhammad, 2012) bahwa, penggunaan mind map memiliki manfaat dalam menunjang kegiatan pembelajaran, "terdiri dari (a) melihat gambaran materi secara menyeluruh dan jelas; (b) melihat dengan detail materi. mind map memberikan kemudahan karena dikemas dalam bentuk digital.

Berbagai kemudahan dan dampak positif penggunaan mind map digital sangat mempermudah dan menarik perhatian pengguna yakni peserta didik. Namun, terdapat beberapa kelemahan dalam media mind map berbasis digital. Media digital hanya dapat diakses melalui laptop (PC). Pembaca atau peserta didik yang tidak memiliki laptop yang dimaksud kemungkinan besar tidak dapat mengakses media ini secara langsung meskipun media mind map digital memiliki fiture cetak (print) sehingga dapat mencetak terlebih dahulu. Landasan teori yang mendasari penelitian ini meliputi media pembelajaran, mind map, aplikasi mindjet mindmanager, materi atmosfer, dan keterkaitan mind map digital dengan materi atmosfer. Masing-masing tersebut dipaparkan sebagai berikut.

\subsection{Media Pembelajaran}

Media merupakan alat bantu belajar yang berperan penting dalam menunjang proses pembelajaran sehingga memudahkan peserta didik dalam belajar. Media pembelajaran berpengaruh terhadap motivasi belajar peserta didik. Media pembelajaran tidak hanya memiliki tampilan yang menarik tetapi perlu menampilkan materi pelajaran yang dikemas dengan baik. Rusman (2013) juga berpendapat bahwa, "media pembelajaran adalah salah satu 
komponen proses belajar mengajar yang memiliki peranan sangat penting dalam menunjang keberhasilan proses belajar mengajar".

Pada strategi pembelajaran, media memiliki posisi yang sejajar dengan bahan dan sumber belajar. Media tidak hanya menjadi alat untuk meyampaikan materi, namun juga dapat menjadi sumber belajar bagi peserta didik. Disamping peranannya yang sangat penting, media memiliki fungsi yang strategis di dalam pembelajaran. Menurut Kempt dan Dayton (dalam Rusman, 2013) fungsi utama media pembelajaran terdiri dari, yaitu: (1) memotivasi minat dan tindakan; (2) menyajikan informasi; dan (3) memberi instruksi.

Penjelasan diatas media pembelajaran yang berfungsi untuk memotivasi minat dan tindakan pada umumnya mampu menarik perhatian peserta didik. Oleh karena itu, peserta didik akan berminat atau tertarik terhadap media maupun materi yang disajikan, media juga berfungsi untuk menyajikan informasi menjadi lebih mudah dipahami, dan fungsi lain media yakni untuk memberi instruksi artinya di dalam media berisi arahan untuk membantu peserta didik dalam belajar.

\subsection{Mind map}

Mind map adalah cara termudah untuk menempatkan informasi ke dalam otak dan mengambil informasi ke luar dari otak, Buzan (2005). Sesuai dengan pendapat tersebut, Sidh dan Saleem (2013) berpendapat bahwa "mind map merupakan media pembelajaran dengan cara membuat catatan tangan pendek dalam bentuk grafis yang bisa membantu meringkas dalam mengingat konsep-konsep penting lebih cepat". Menurut Long dan Daniel (2011) "peta pikiran pada dasarnya representasi visual pemikiran peserta didik, yang memungkinkan peserta didik untuk mendapatkan informasi secara lebih luas". Media pembelajaran mind map, dapat meningkatkan aktivitas dan hasil belajar peserta didik pada kompetensi dasar dinamika atmosfer. Hal ini akan mendorong seseorang untuk memahami, belajar, berpikir, dan bertindak. Peranan guru dalam pembelajaran memang sangat penting. Guru tidak hanya berperan sebagai penyampai informasi. Guru juga bertindak sebagai pengarah dan pemberi fasilitas untuk terjadinya proses belajar, Ali (2008).

Penjelasan diatas mengenai penggunaan mind map, peserta didik dapat mengembangkan imajinasi karena mampu mengaitkan konsep-konsep materi yang tersedia dalam bentuk peta pikiran yang menarik sehingga mudah diingat dan sejalan dengan cara kerja alami otak. Konsep-konsep yang sudah terdapat di otak dengan cara yang mudah dan menyenangkan membuat mind map menjadi media yang sesuai untuk diterapkan kepada peserta didik terutama pada pelajaran dengan pembahasan materi yang banyak.

\subsection{Mindjet mindmanager}

Program mindjet mindmanager dapat digunakan untuk membuat presentasi peta pikiran, sehingga membantu mempercepat dalam pembuatan peta pikiran dengan menarik. Pendapat Nanang (2013) menjelaskan bahwa, "mindjet mindmanager sangat fleksibel dapat mengganti dan memodifikasi peta pikiran. Software ini memiliki kemampuan untuk membuat tautan (link) dengan aplikasi lain, misalnya power point, word, excel, dan macromedia flash". Pendapat Cameron, Voight (2004) menjelaskan bahwa, "mindjet mindmanager adalah produk sofware yang unik, peta pikiran dengan menggunakan mindjet mindmanager memberikan sebuah tampilan dengan stuktur peta dirancang untuk mengintegrasikan ikon, grafis, dan 
elemen visual lainnya dengan bahan teks. Tata letak peta dapat menyajikan informasi secara visual".

Menggunakan aplikasi mindjet mindmanager akan mempermudah guru dalam menyampaikan bahan ajar. Sebuah inovasi baru mind map pada aplikasi mindjet mindmanager yang lebih menarik sehingga peserta didik lebih termotivasi pada proses pembelajaran. Pendapat beberapa ahli tersebut dapat disimpulkan bahwa mindjet mindmanager adalah alat yang digunakan sebagai perantara komunikasi dalam kegiatan pembelajaran geografi dengan memanfaatkan program pembuat presentasi mind map digital yang dapat diakses secara online maupun offline. Mindjet mindmanager merupakan aplikasi yang mudah digunakan karena fitur yang tersedia memiliki kesamaan dengan aplikasi ms.word, selain itu mindjet mindmanager dapat di export melalui HTML5, pdf, image, swf, ms.word, ms. powerpoint. Namun, aplikasi mindjet mindmanager memiliki kelemahan berupa ukuran data aplikasi yang besar, bentuk mind map tidak dapat dimodifikasi terlalu banyak karena telah otomatis dari program mindjet mindmanager, besarnya bentuk setiap diagram menyesuaikan dengan isi materi.

\subsection{Materi Atmosfer}

Atmosfer merupakan bagian bumi yang paling penting. Selubung bumi tersebut berupa lapisan udara yang disebut atmosfer. Atmosfer terdiri dari bermacam-macam unsur gas dan didalamnya terjadi proses perubahan dan pembentukan cuaca dan iklim. Atmosfer melindungi manusia dari sinar matahari yang berlebihan dan dari jatuhnya meteor-meteor luar angkasa yang menuju ke bumi. Atmosfer juga melindungi bumi dari suhu dingin membeku ruang angkasa yang mencapai sekitar $270 \mathrm{oC}$ dibawah nol serta berperan dalam memperkecil perbedaan temperatur siang dan malam. Gas penyusun atmosfer adalah nitrogen (78 \%), oksigen (21\%), argon (0,9\%), dan karbon dioksida (0,03\%).

Keberlangsungan dinamika di atmosfer dan kehidupan di bumi, digerakkan dengan energi dari matahari. Matahari dengan reaksi fusi (menggabungkan 2 energi) yang telah terus berlangsung miliyaran tahun, secara berkelanjutan mengemisikan dan meradiasikan energi dalam jumlah yang sangat besar. Energi ini yang sampai ke atmosfer luar bumi, terlalu besar untuk kehidupan di permukaan bumi. Atmosfer dengan lapisan gas-gas yang spesifik, menggunakan untuk reaksi, memantulkan, menyerap (absorb) dan menyaring (filter) energi matahari dalam jumlah yang sangat besar tersebut. Hanya sebagian kecil yang diteruskan sampai ke permukaan bumi.

Berdasarkan pendapat para ahli, atmosfer adalah materi dalam geografi fisik yang membahas tentang lapisan udara yang menyelimuti seluruh permukaan bumi beserta fenomena atmosfer yang terjadi di kehidupan sehari-hari. Selain itu unsur iklim sangat mempengaruhi kehidupan makhluk hidup. Perubahan yang saat ini dirasakan adalah adanya pemanasan global yang disebabkan karena tidak seimbangnya ekosistem di bumi dengan suhu yang terus meningkat sehingga berpengaruh terhadap perubahan pada sistem kehidupan makhluk hidup. Materi atmosfer memiliki subtema materi yang cukup banyak dan perlu media yang sesuai dalam pembelajaran materi atmosfer. 


\section{Metode}

Metode yang digunakan dalam pengembangan ini adalah Research and Development (R\&D). Metode penelitian dan pengembangan merupakan cara untuk menemukan, mengembangkan, dan menguji hasil produk berdasarkan prosedur yang telah ditentukan. Sesuai dengan pendapat Sukmadinata (2012) Penelitian dan pengembangan adalah suatu proses untuk mengembangkan suatu produk baru atau menyempurnakan produk yang telah ada.

Model pengembangan media pembelajaran dalam penelitian menggunakan model pengembangan ADDIE. Istilah ADDIE merupakan singkatan dari Analysis, Design, Develop, Implement, dan Evaluation (Branch, 2009). Namun, peneliti melakukan Prosedur pengembangan perangkat ini terdiri dari 3 tahap, sesuai dengan penelitian dan pengembangan tingkat 1 yaitu analysis, design, and development. Beberapa aspek yang perlu diketahui dalam tahap penelitian meliputi: 1) penelitian terhadap potensi dan masalah yang ada, 2) studi literatur dan pengumpulan informasi, dan 3) perencanaan atau membuat desain dan pengujian internal produk dengan ahli. Hasil output berupa mind map digital untuk peserta didik SMA kelas X pada materi atmosfer dan responnya oleh praktisi lapangan peserta didik.

Penelitian dan pengembangan ini menggunakan jenis data berupa data kualitatif berupa hasil observasi dan wawancara pada tahap penelitian dan lembar validasi ahli dan data kuantitatif angket peserta didik. Data kualitatif yang berasal dari lembar validasi ahli berupa saran dan komentar dari validator. Data kualitatif yang diperoleh dari saran dan komentar validator ahli digunakan sebagai acuan dasar dalam melakukan revisi. Data kuantitatif yang diperoleh dari peserta didik berupa tanggapan terhadap media mind map digital untuk peserta didik SMA kelas X IPS 4 pada materi atmosfer. Berikut adalah rancangan pelaksanaan pengembangan media mind map digital.

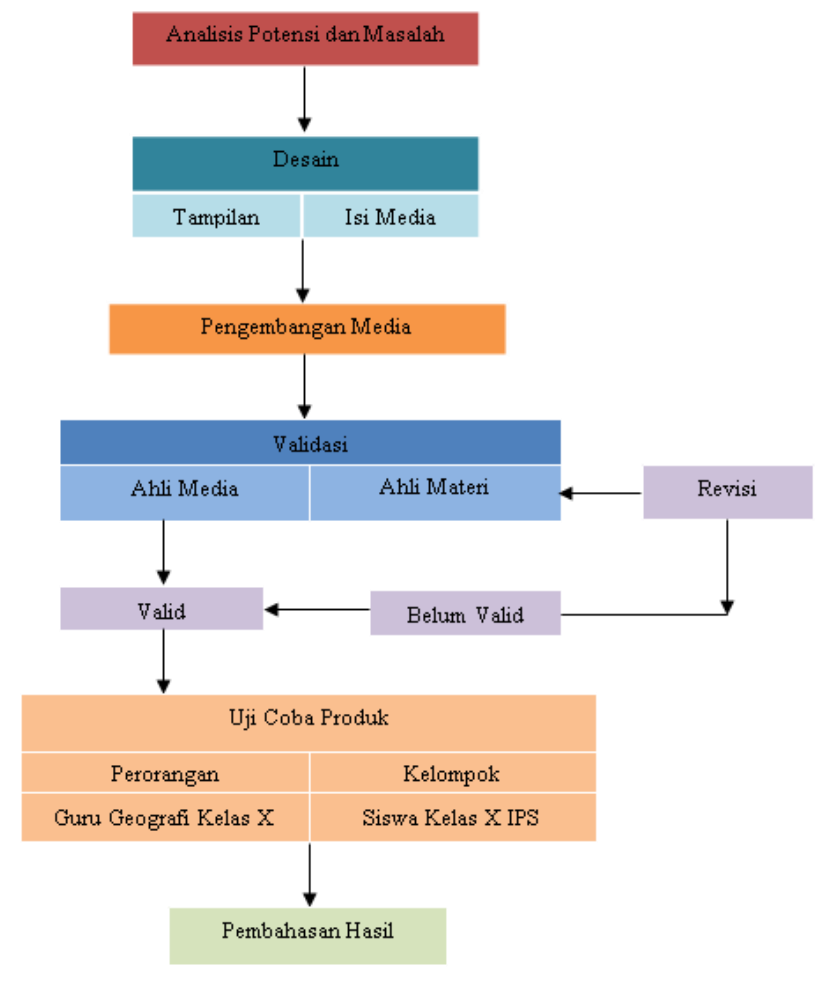

Gambar 1. Rancangan Pelaksanaan Pengembangan (modifikasi model ADD) 
Teknik analisis data pada penelitian ini menggunakan analisis kualitatif deskriptif, data yang diperoleh dari penilaian angket ahli materi dan ahli media. Teknik analisis ini dilakukan dengan cara mengelompokan informasi saran dan rekomendasi yang terdapat pada lembar validasi. Hasil data ini kemudian digunakan untuk merevisi produk yang dikembangkan. Sedangkan analisis data kuantitatf dari peserta didik akan disajikan dalam bentuk deskriptif presentase. Berikut adalah tabel kelayakan media.

Tabel 1. Kriteria Kelayakan Media

\begin{tabular}{llll}
\hline Nilai & Total Skor & Kualifikasi & Keputusan dan Tindak Lanjut \\
\hline A & $80,1-100,0$ & Sangat Layak & Bisa digunakan tanpa revisi \\
B & $60,1-80,0$ & Layak & Bisa digunakan tapi perlu revisi kecil \\
C & $40,1-60,0$ & Kurang Layak & Bisa digunakan tapi perlu revisi besar \\
D & $20,1-40,0$ & Tidak Layak & Tidak bisa digunakan perlu perbaikan total \\
& E & $00,0-20,0$ & Sangat Tidak Layak \\
\hline
\end{tabular}

Sumber: Adaptasi dari Tabel Akbar, (2013)

Rentangan analisis nilai tes media pembelajaran menggunakan presentase jumlah peserta didik. Kelayakan media pembelajaran dikatakan layak digunakan apabila lebih dari $70 \%$ jumlah peserta didik mendapatkan nilai baik atau sangan baik.

\section{Hasil dan Pembahasan}

Data yang diperoleh pada penelitian dan pengembangan mind map digital tentang atmosfer ini berupa total skor angket. Data hasil uji coba diperoleh dari 28 peserta didik kelas X IPS 4 SMA 2 Batu. Data tersebut digunakan untuk melihat seberapa jauh kelayakan media pembelajaran.

\subsection{Analisis Data Uji Internal}

Validasi dilakukan untuk mengetahui kelayakan produk yang telah dibuat untuk diuji cobakan pada pembelajaran di sekolah. Data internal berasal dari saran dan rekomendasi validator ahli. Berikut identitas validator media dan validator materi pada produk media mind map digital untuk peserta didik SMA kelas $\mathrm{X}$ materi Atmosfer pada penelitian dan pengembangan ini.

\section{Tabel 2. Hasil Validasi Media}

\begin{tabular}{cll}
\hline No & Kesalahan & Rekomendasi \\
\hline 1. & $\begin{array}{l}\text { Tingkat cabang mind } \\
\text { map }\end{array}$ & $\begin{array}{l}\text { Pada tingkat cabang mind map hubungannya perlu diperluas } \\
\text { lagi sehingga menjadi lebih detail, karena mind map setiap } \\
\text { cabang harus saling berhubungan } \\
\text { Bentuk bagan pada mind map belum proporsional dan } \\
\text { konsisten, sehingga diteliti lagi bentuk bentuk bagan agar } \\
\text { seragam. }\end{array}$ \\
$\begin{array}{lll}\text { Bentuk bagan } \text { mind } \\
\text { map kurang proporsi }\end{array}$ & $\begin{array}{l}\text { Perlu ditambah contoh baik berupa gambar maupun video } \\
\text { agar pengguna lebih tertarik, karena penggunaan gambar } \\
\text { ataupun video dapat menambah ketertarikan pengguna dalam } \\
\text { belajar }\end{array}$ \\
\hline
\end{tabular}




\section{Tabel 3. Hasil Validasi Materi}

\begin{tabular}{|c|c|c|}
\hline No & Kesalahan & Rekomendasi \\
\hline 1. & Kelengkapan materi & $\begin{array}{l}\text { Materi troposfer lebih detail penjelasannya berdasarkan } \\
\text { keruangan, karena geografi identik dengan keruangan } \\
\text { yang setiap tempat memiliki perbedaan berdasarkan garis } \\
\text { lintang. }\end{array}$ \\
\hline 2. & $\begin{array}{l}\text { Bahasa yang } \\
\text { digunakan }\end{array}$ & $\begin{array}{l}\text { Bahasa yang digunakan dalam penjelasan materi lebih } \\
\text { dibahasakan secara sederhana agar pengguna lebih } \\
\text { memahami materi }\end{array}$ \\
\hline 3. & $\begin{array}{l}\text { Ilustrasi materi } \\
\text { (gambar dan } \\
\text { video/animasi) }\end{array}$ & $\begin{array}{l}\text { Memberikan contoh yang sesuai dengan topik pembahasan } \\
\text { materi berupa gambar maupun video agar pengguna lebih } \\
\text { tertarik, karena penggunaan gambar ataupun video dapat } \\
\text { menambah ketertarikan pengguna dalam belajar }\end{array}$ \\
\hline
\end{tabular}

\subsection{Analisis Data Respon Peserta Didik}

Analisis data kuantitatif dilakukan saat seluruh data respon peserta didik terkumpul. Berdasarkan hasil perhitungan aspek penilaian dari angket peserta didik, secara keseluruhan media mind map digital untuk peserta didik SMA kelas X pada materi atmosfer memiliki ratarata $80,02 \%$ dan memiliki kategori "Sangat layak/sangat menarik". Peserta didik tertarik menggunakan mind map digital berdasarkan segi materi maupun kualitas media. Penggunaan mind map digital untuk peserta didik SMA kelas X pada materi atmosfer dapat meningkatkan motivasi semangat belajar peserta didik karena dapat mudah untuk digunakan dalam belajar salah satunya dalam pemahaman pelajaran. Berikut tabel hasil uji coba.

Tabel 4. Hasil Uji Coba

\begin{tabular}{llllll}
\hline No & Aspek Penilaian & $\sum \mathrm{X}$ & $\sum \mathrm{Xi}$ & $\%$ & Keterangan \\
\hline 1. & Kemenarikan & 455 & 1792 & 80,02 & Sangat layak \\
2. & Kenyamanan & 438 & & & \\
3. & Kemudahan & 541 & & & \\
\hline Jumlah & 1434 & & & \\
\hline
\end{tabular}

\subsection{Kajian Produk Yang Telah Direvisi}

Hasil akhir dari penelitian dan pengembangan yang telah dilaksanakan yaitu media pembelajaran berupa mind map digital untuk SMA Kelas X pada materi atmosfer. Pengembangan media berupa mind map digital untuk peserta didik SMA kelas X pada materi atmosfer perlu dilakukan karena belajar menggunakan teknologi menjadi bagian dari pembelajaran saat ini. Teknologi berkembang dengan pesat, salah satu pemanfaatannya dibidang pendidikan. Berbagai informasi dapat diakses secara cepat, kapanpun dan dimanapun menggunakan teknologi digital. Kemudahan penggunaan teknologi menjadikan salah satu alasan untuk melakukan inovasi terhadap proses pembelajaran.

Inovasi pembelajaran yang dilakukan saat ini salah satunya menyesuaikan dengan karakteristik peserta didik termasuk generasi milenial yang dalam kegiatan belajar menggunakan laptop (PC) dan internet. Selain itu, perubahan kurikulum belajar saat ini menjadi kurikulum 2013 menuntut dunia pendidikan harus dapat beradaptasi dan menyediakan media berbasis teknologi digital untuk mengimbangi gaya hidup peserta didik 
sebagai generasi milenial (Puspita, 2018). Pengembangan media mind map digital selaras dengan pernyataan tersebut. Pergeseran penggunaan media cetak berbasis konvensional menjadi digital akan menambah ketertarikan peserta didik untuk menggunakan media mind map digital. Pendapat ini juga selaras dengan pernyataan Arsyad (2014) media pembelajaran merupakan alat bantu yang dapat digunakan untuk menyampaikan pesan atau informasi dalam proses belajar yang menarik sehingga dapat merangsang perhatian dan minat peserta didik dalam belajar. Keunggulan lain yang ada pada mind map digital berbasis mindjet mindmanager dapat membuat peta pikiran yang interaktif dan terorganisir sehingga mampu menyampaikan ide serta informasi secara efektif, menarik dan mudah dipahami. Mind map dikembangkan penggunaannya menjadi bentuk digital karena untuk memberikan kemudahan dalam memahami materi pelajaran dengan berbantuan teknologi agar penggunaan media lebih mudah dan menarik.

Desain rancangan mind map digital untuk peserta didik SMA kelas X pada materi atmosfer yang dikembangkan telah didesain dengan baik untuk menarik perhatian peserta didik. Materi yang dibahas dalam mind map digital untuk peserta didik SMA kelas X pada materi atmosfer berisi penjelasan subtema secara ringkas, uraian, dan contoh-contoh materi atmosfer baik berupa, gambar, video, web. Produk akhir mind map digital untuk peserta didik SMA kelas $\mathrm{X}$ pada materi atmosfer berupa file HTML yang dikemas melalui tampilan awal autoplay media studio yang berformat exe yang dapat digunakan melalui bantuan layar digital yang hanya bisa ditampilkan secara desktop base melalui laptop (PC).

Produk yang dikembangkan telah melalui tahap uji internal berupa validasi dari ahli pada masing-masing bidang, yaitu materi dan media. Kritik dan saran dari validator yang berupa rekomendasi menjadi acuan dalam proses revisi produk. Produk yang telah direvisi kemudian diaplikasikan peserta didik kelas X IPS 4 di SMAN 2 Batu yang berjumlah 28 peserta didik untuk mengetahui kemenarikan produk yang dikembangkan. Uji coba produk media tidak digunakan sebagai acuan valid atau tidaknya media pembelajaran yang dikembangkan, melainkan hanya sebatas untuk mengetahui kemenarikan penggunaan produk media mind map digital dalam kegiatan belajar dan pembelajaran.

Tanggapan peserta didik melalui data angket saat uji coba lapangan menunjukan bahwa media mind map digital untuk peserta didik SMA kelas X pada materi atmosfer memiliki kategori sangat layak atau sangat menarik untuk digunakan dalam pembelajaran. Media juga dapat membangkitkan semangat dan motivasi, serta pemahaman belajar peserta didik. Secara keseluruhan melalui angket peserta didik dapat diketahui persentase kemenarikan media mind map digital sebesar $80,02 \%$ yang dapat dikategorikan sangat layak/sangat menarik (Akbar, 2013).

\section{Simpulan}

Penelitian dan pengembangan ini dilakukan untuk menghasilkan produk media mind map digital berbasis aplikasi mindjet mindmanager. Produk tersebut berupa peta pikiran yang dikemas dalam bentuk digital, sehingga dapat dioperasikan oleh laptop (PC) dengan tampilan desktop base agar peserta didik lebih tertarik untuk belajar dan proses pembelajaran yang dilaksanakan menjadi lebih mudah. Berdasarkan uraian yang telah dikemukakan di atas, dapat diketahui bahwa masing-masing aspek dari produk media hasil pengembangan telah layak digunakan dalam proses pembelajaran. Secara keseluruhan uji coba produk hasil pengembangan memperoleh skor sebanyak 1434 dengan nilai persentase sebesar 80,02\%. 
Hasil tersebut menunjukkan bahwa produk media yang telah dikembangkan termasuk dalam kualifikasi layak secara keseluruhan. Dengan demikian, media mind map digital berbasis aplikasi mindjet mindmanager pada materi atmosfer sudah bisa dan layak digunakan dalam proses belajar mengajar di dalam kelas.

\section{Daftar Rujukan}

Akbar, S. D. (2013). Instrumen perangkat pembelajaran.

Alamsyah, M. (2009). Kiat jitu meningkatkan prestasi dengan Mind Mapping. Yogyakarta: Mitra Pelajar.

Arsyad, A. (2011). Media pembelajaran. Jakarta: Pt. Raja Grafindo Persada.

Branch, M. (2009). Instructional Design: The Addie Approach. Us: Boston Speinger.

Buzan, T. (2005). Use Your Memory. Great Britain: The British Broadcasting Corp.

Buzan, T. (2008). Buku Pintar Mind Map. Jakarta: PT. Gramedia Pustaka Utama

Cameron, H. \& Roger V. (2004). Mindmanager For Dummies. Indianapolis, Indiana: Wiley Publishing, Inc.

Fatkurrohman, F. (2013). Pengembangan media CD pembelajaran interaktif pada mata pelajaran geografi kelas $X$ semester II topik atmosfer. SKRIPSI Jurusan Geografi-Fakultas Ilmu Sosial UM.

Azhar, A. (2007). Media pembelajaran, Jakarta: PT. Raja Grafindo Persada, 15-85.

Nanang, Dkk. (2013). Pengembangan Program Aplikasi Mindjet Mindmanager. Jurnal Teknologi Informasi. (Vol. 1, Hal 3-4)

Sidh, M. S., \& Saleem, N. H. (2013). Interactive Multimedia Cognitive Mind Mapping Approach in Learning Geography. Multimedia Technology (MT) Volume, 2. Sukmadinata. 2016. Pengembangan Kurikulum Teori Dan Praktik. Bandung: Pt Remaja Rosdakarya.

Long, D. J., \& Carlson, D. (2011). Mind the map: How thinking maps affect student achievement. Journal for Teacher Research, 13(2), 262-262.

Puspita, G. A., \& Irwansyah, I. (2018). Pergeseran budaya baca dan perkembangan industri penerbitan buku di Indonesia: Studi kasus pembaca E-Book melalui aplikasi iPusnas. BIBLIOTIKA: Jurnal Kajian Perpustakaan dan Informasi, 2(1), 13-20. 